\title{
OPTIMALISASI FASILITAS ALAT PRAKTIK UNTUK MENCAPAI TUNTUTAN KOMPETENSI SISWA SMK
}

\author{
Siti R. Tazkiah', Amay Suherman², Yayat $^{3}$ \\ Departemen Pendidikan Teknik Mesin \\ Universitas Pendidikan Indonesia \\ Jl. Dr. Setiabudhi No. 207 Bandung 40154 \\ ct_tazkiah@yahoo.com
}

\begin{abstract}
ABSTRAK
Tujuan penelitian ini untuk mendapatkan informasi tentang jumlah dan jenis alat, efisiensi penggunaan masingmasing alat yang selama ini digunakan pada mata pelajaran Pemeliharaan Mesin Sepeda Motor di kelas XI, upaya yang harus dilakukan untuk mengoptimalkan fasilitas alat praktik untuk mencapai tuntutan kompetensi pada mata pelajaran Pemeliharaan Mesin Sepeda Motor di kelas XI. Sehingga nilai efisiensi penggunaannya menjadi lebih efisien. Penelitian ini menggunakan metode penelitian deskriptif dengan instrumen wawancara, dokumentasi dan observasi. Temuan penelitian terdapat lima jenis job yang harus diselesaikan siswa pada mata pelajaran Pemeliharaan Mesin Sepeda Motor kelas XI. Ada 41 jenis alat dengan jumlah bervariasi. Nilai efisiensi penggunaan alat kerja praktik dari 41 jenis alat tersebut yaitu 60\%, maka penggunaan alat praktik tidak efisien karena jumlah alat berlebih dalam artian tidak digunakan. Setelah dioptimalkan maka nilai efisiensinya menjadi $87 \%$, maka penggunaan alat praktik menjadi efisien.
\end{abstract}

Kata kunci: optimalisasi, fasilitas, alat praktik, pemeliharaan mesin, sepeda motor.

\section{PENDAHULUAN}

Pendidikan kejuruan merupakan suatu program pendidikan yang mempersiapkan Sumber Daya manusia (SDM) agar memiliki keahlian spesifik yang berorientasi pada dunia kerja. Menurut Undang-undang sisdiknas Nomor 20 Tahun 2003 menjelaskan bahwa pendidikan kejuruan merupakan pendidikan yang mempersiapkan peserta didik untuk dapat bekerja dalam bidang tertentu. Tujuan pendidikan kejuruan yaitu untuk meningkatkan kecerdasan, pengetahuan, kepribadian, ahlak mulia serta keterampilan peserta didik untuk hidup mandiri dan mengikuti pendidikan lebih lanjut sesuai dengan program kejuruannya.

Pendidikan menengah kejuruan adalah pendidikan pada jenjang pendidikan menengah yang mengutamakan pengembangan kemampuan siswa untuk jenis pekerjaan tertentu. Pendidikan menengah kejuruan pada dasarnya bertujuan untuk menyiapkan tenaga kerja berkualitas yang memiliki pengetahuan, keterampilan, dan sikap yang sesuai dengan bidang kejuruan dan kebutuhan dunia kerja. Salah satu cara untuk menciptakan lulusan Sekolah Menengah Kejuruan (SMK) yang sesuai dengan tujuan tersebut, maka harus disusun kurikulum yang memiliki langkah nyata dalam penerapannya terutama penerapan kompetensinya (Kuswana, 2013). Kompetensi yang telah ditetapkan oleh dunia usaha/dunia

\footnotetext{
${ }^{1}$ Mahasiswa Departemen Pendidikan Teknik Mesin FPTK UPI

2 Dosen Departemen Pendidikan Teknik Mesin FPTK UPI

${ }^{3}$ Dosen Departemen Pendidikan Teknik Mesin FPTK UPI
} 
industri dikemas dalam berbagai mata diklat yang dikelompokan menjadi mata pelajaran Normatif, Adaptif, dan Produktif.

Kenyataan yang terjadi pada saat ini yaitu masih ada sekolah khususnya SMK yang belum memenuhi kebutuhan akan pengadaan sarana dan prasarana yang memadai untuk proses pembelajaran. Tercapainya tujuan pendidikan kejuruan dipengaruhi oleh beberapa faktor, salah satu diantaranya adalah ketersediaan sarana dan prasarana pendidikan yang memadai. Mengacu pada Peraturan Pemerintah Nomor 19 Tahun 2005 Tentang Standar Nasional Pendidikan Pasal 42 disebutkan bahwa: setiap satuan pendidikan wajib memiliki sarana yang meliputi perabot, peralatan pendidikan, media pendidikan, buku dan sumber belajar lainnya, bahan habis pakai, serta perlengkapan lain yang diperlukan untuk menunjang proses pembelajaran yang teratur dan berkelanjutan. Setiap satuan pendidikan wajib memiliki prasarana yang meliputi lahan, ruang kelas, ruang pimpinan satuan pendidikan, ruang pendidik, ruang tata usaha, ruang perpustakaan ruang laboratorium, ruang bengkel kerja, ruang unit produksi, ruang kantin, instalasi daya dan jasa, tempat berolahraga, tempat beribadah, tempat bermain, tempat berkreasi, dan ruang/tempat lain yang diperlukan untuk menunjang proses pembelajaran yang teratur dan berkelanjutan.

Sarana pendidikan di SMK memegang peranan penting karena dapat berguna untuk menunjang proses belajar mengajar, baik secara langsung maupun tidak langsung dalam rangka mencapai tujuan pendidikan. Secara umum, proses kegiatan belajar mengajar di SMK meliputi pembelajaran teori dan pembelajaran praktik, untuk menunjang kegiatan pembelajaran praktik di SMK diperlukan saran dan prasarana yang memadai seperti bengkel serta perlengkapan alat praktik. Fasilitas pembelajaran seperti kebutuhan modul analisis dan peralatan, ketersediaan ruangan serta jumlah guru yang cukup. Khusus untuk kebutuhaan alat dan bahan harus mengacu pada rasio kecukupan satu siswa satu alat dan bahan serta memadai dalam jenis dan jumlah sesuai dengan tuntutan kompetensi.

Rasio antara jumlah siswa dengan jumlah alat dan bahan praktik yaitu satu alat hanya digunakan oleh satu siswa, serta memadai dalam jenis dan jumlah sesuai dengan tuntutan kompetensi. Kebutuhan alat praktik harus diperhitungkan untuk mencapai efisiensi penggunaan alat dapat tercapai. Menentukan efisiensi penggunaan alat praktik harus mempertimbangkan beberapa faktor, seperti jumlah siswa dan jumlah jam pelajaran. Ruangan praktik adalah tempat penyelenggaraan pelajaran praktik yang berbeda-beda sifat dan persyaratannya, sehingga tiap jenis atau macam ruangan harus di hitung jenis per-jenis. Oleh 
sebab itu, faktor jumlah siswa dan jumlah jam pelajaran per-minggu menurut semester merupakan faktor penentu dalam menghitung kebutuhan ruangan praktik.

Peralatan praktik memiliki peranan yang sangat penting dalam rangka menunjang kegiatan pembelajaran di SMK. Alat peralatan adalah identitas atau ciri khas dari SMK dan sekaligus merupakan sarana pokok. Perhitungan yang kurang tepat dan efektifitas yang rendah,merupakan suatu kerugian. Sebaliknya bila diwaktu-waktu praktik siswa atau beberapa siswa sering tidak kebagian pemakaian alat, berarti target siswa belajar tidak tercapai. Efisiensi penggunaan alat kerja praktik sangat penting agar target pembelajaran bisa tercapai, Setiap siswa harus melaksanakan praktik. Jika ada siswa yang menganggur, maka itu merupakan kerugian. Menurut standar Astra Honda Motor menyatakan bahwa satu training object digunakan untuk 2 orang.

Jumlah alat praktik yang tesedia untuk pelaksanaan praktik pada mata pelajaran Pemeliharaan Mesin Sepeda Motor hanya terdapat sembilan unit sepeda motor. Pelajaran tersebut diberikan kepada siswa kelas XI Jurusan Teknik Sepeda Motor dengan jumlah siswa 183 orang yang dibagi menjadi tujuh kelas. Sehingga dengan kondisi alat dan jumlah siswa tersebut, menggambarkan bahwa rasio antara alat dan siswa adalah 1:20. Artinya 1 alat dalam waktu yang bersamaan di gunakan oleh 26 siswa. Apabila berdasarkan jumlah siswa perkelas rasio antara alat dan siswa adalah 1:3.

Kegiatan pembelajaran praktik pada mata pelajaran Pemeliharaan Mesin Sepeda Motor terbagi menjadi lima jenis job yaitu: overhaul kepala sislinder, overhaul blok sislinder, overhaul sistem pendingin, overhaul sistem pelumasan, dan perbaikan sistem pengaliran bahan bakar bensin konvensional. Satu kelas terbagi jadi tujuh kelompok yang masing-masing kelompok terdiri dari empat atau lima orang, dengan jumlah satu guru. Kegiatan praktik tersebut dialokasikan enam jam pertemuan dalam waktu satu minggu. Setiap siswa hanya mendapat satu kali kesempatan melaksanakan praktik dalam satu job.

Tidak mengherankan banyak siswa yang belum mampu menguasai mata pelajaran Pemeliharaan Mesin Sepeda Motor. Kondisi ini menunjukkan bahwa pada mata pelajaran tersebut masih memerlukan pembenahan dalam berbagai aspek yang terkait dengan pelaksanaan Kegiatan Belajar Mengajar (KBM). Pembenahan yang harus dilakukan tersebut, diantaranya adalah dengan mengoptimalkan metode pembelajaran praktik yang akan digunakan berdasarkan jumlah dan jenis alat yang ada agar tuntutan kompetensi bisa tercapai. 


\section{METODE PENELITIAN}

Metode penelitian yang digunakan pada penelitian ini adalah metode deskriptif. Penelitian ini dilakukan untuk menyelidiki keadaan, kondisi atau hal-hal lain yang sudah disebutkan, yang hasilnya dipaparkan dalam bentuk laporan. Penelitian ini merupakan studi kasus sehingga tidak menguji hipotesis melainkan hanya memaparkan keadaan suatu kondisi secara riil tanpa ada manipulasi atau campur tangan yang mempengaruhi subjek penelitian.

\section{HASIL PENELITIAN}

Jenis job dan alokasi waktu pada mata pelajaran Pemeliharaan Mesin Sepeda Motor yaitu terdapat enam jenis kompetensi dasar yang terbagi menjadi enam job. Job tersebut harus diselesaikan oleh setiap siswa dalam waktu satu semester. Namun ada dua Job yang digabung menjadi satu yaitu job memperbaiki karburator dan job perbaikan sistem bahan bakar konvensional. Jenis alat yang dibutuhkan setiap job pada mata pelajaran Pemeliharaan Mesin Sepeda Motor harus sesuai dengan kompetensinya. Job yang paling banyak membutuhkan alat yaitu job overhaul kepala silinder, dan job yang membutuhkan alat paling sedikit yaitu job overhaul sistem pelumasan.

Jumlah alat yang tersedia di ruang alat teknik sepeda motor dalam kategori lengkap dari segi jenis peralatan yang dibutuhkan dalam pelaksanaan pembelajaran praktik. Sesuai Panduan Penerapan Teknik Sepeda Motor Honda Sekolah Menengah Kejuruan (SMK), tentang standard tools and equipment yang harus dimiliki sekolah. Pengelompokan alat diantaranya: strategic tools, measerement tools, common tools, special tools cub/sport, special tools matic, dan equipment.

Ketersediaan peralatan adalah kuantitas yang dimiliki setiap jenis peralatan relatif sama jumlahnya yaitu sembilan. Alat yang paling banyak jumlahnya yaitu jangka sorong ada 12 . Alat yang paling sedikit jumlahnya yaitu unit engine sepeda motor cub, cutter valve dan float level ada tiga. Begitu pula dengan status alat semua berstatus working station ganda (WSG), karena alat digunakan lebih dari satu siswa.

\section{PEMBAHASAN}

Menghitung efesiensi penggunaan alat praktik harus diketahui beberapa hal diantaranya: jumlah regu kerja, sebaran alat praktik, alokasi waktu pada tiap job selama kegiatan pembelajaran praktik dan nilai efisiensi penggunaan alat praktik. 
Pembagian regu kerja pada setiap kelas, yaitu peserta berjumlah 12 orang, dan dibagi menjadi enam kelompok (satu kelompok dua orang). Jumlah kelompok di sekolah sangat jauh berbeda dengan ketentuan instruksi kerja di AHM. Pendistribusian alat pada mata pelajaran Pemeliharaan Mesin Sepeda Motor semua alat pada tiap job rata-rata memiliki jumlah yang sama yaitu dua alat yang digunakan. Kecuali unit engine sepeda motor cub ada yang mendapatkan dua unit pada satu job dan satu unit pada tiga job. Pendistribusian dua alat pada tiap job karena, pada setiap praktik ada yang melakukan dua job yang sama. Sselain itu, tujuan dari pendistribusian alat yaitu untuk memeratakan penggunaan alat karena ada beberapa jenis alat yang digunakan pada job yang berbeda. Tujuan lainnya adalah untuk menjamin nilai efisiensi yang dihitung hasilnya supaya benar, karena efisisensi yang penulis hitung pada penelitian ini adalah efisiesnsi alat per kelompok job (Astra Honda Motor, 2011).

Pembelajaran praktik pada mata pelajaran Pemeliharaan Mesin Sepeda Motor dilakukan sebanyak lima kali sesuai dengan jumlah job, dalam waktu lima minggu pertemuan. Artinya, setiap siswa melaksanakan praktik satu kali pada setiap job. Alokasi waktu tiap minggu pertemuan adalah enam jam pelajaran, dimana empat jam pelajaran untuk praktik dan dua jam pelajaran untuk membuat laporan praktik (Syafrudie, 2004).

Perhitungan nilai efisiensi penggunaan alat praktik disesuaikan dengan pelaksanaan pembelajaran praktik pada mata pelajaran Pemeliharaan Mesin Sepeda Motor. Nilai efisiensi penggunaan alat praktik pada mara pelajaran Pemeliharaan Mesin Sepeda Motor rata-rata $<70 \%$. Nilai tersebut menunjukkan bahwa secara umum penggunaan alat praktik tidak efisien. Namun, jumlah alat yang tersedia banyak tetapi hanya sedikit alat yang digunakan sesuai dengan jumlah kelompok.

Nilai efisiensi penggunaan alat kerja praktik yang tidak efisien dipengaruhi oleh beberapa faktor yaitu jumlah alat tidak semua alat digunakan. Semua status alat menjadi WSG, dan masih ada alat menganggur, jumlah siswa dan alokasi waktu penggunaan alat. Pengaturan penggunaan alat praktik pada daftar pembuatan tugas praktik (DPTP) juga sangat mempengaruhi besar kecilnya nilai efisiensi penggunaan alat kerja praktik. Kreatifitas guru dalam mengatur DPTP dapat menentukan optimalisasi dan nilai efisiensi penggunaan alat kerja praktik.

Suatu alat dapat dikatakan memiliki nilai efisiensi yang baik apabila dapat memenuhi kriteria antara jumlah frekuensi keterpakaian dengan ketersediaan alat berimbang. Sehingga tidak terdapat kondisi dimana alat tidak terpakai karena berlebih atau bahkan rusak akibat dipakai secara berlebih. Efisiensi adalah ketepatan cara (usaha, kerja) dalam menjalankan 
sesuatu (dengan tidak membuang-buang waktu, tenaga, biaya) kedayagunaan atau kemampuan menjalankan tugas dengan baik dan tepat (dengan tidak membuang-buang waktu, tenaga, biaya). Kriteria penggunaan peralatan yang ideal untuk menunjang kegiatan pembelajaran praktik memiliki efisiensi berkisar antara 70\%-90\% (Barnawi dan Arifin, 2012).

Upaya yang harus dilakukan untuk mengoptimalkan fasilitas alat praktik yang ada yaitu dengan cara mengubah jumlah siswa. Temuan di sekolah menunjukkan bahwa jumlah siswa tiap kelas bervariasi, jumlahnya ada yang banyak dan ada yang sedikit. Jumlah siswa tiap kelas diubah menjadi lima kelas dengan jumlah 26 siswa dan satu kelas dengan jumlah 27 siswa. Regu kerja dibuat menjadi 13 regu dengan jumlah anggota dua sampai 3 tiga siswa karena jumlah alat memadai. Selanjutnya upaya untuk mengoptimalkan fasilitas alat praktik yaitu dengan cara mendistribusikan alat sesuai dengan kebutuhan pada setiap job. Siswa melakukan pembelajaran praktik biasanya hanya satu kali pada setiap job dalam satu semester yaitu hanya lima minggu pertemuan. Agar lebih optimal maka siswa melakukan praktik tiga kali setiap job dalam satu semester 15 minggu pertemuan.

Sekolah menengah kejuruan dituntut untuk menyiapkan tenaga kerja yang trampil dan handal. Keterampilan harus sering dilatih. Jika hanya satu kali praktik siswa tidak mungkin bisa trampil, maka dari itu pengulangan praktik pada setiap job perlu dilakukan. Menentukan sebaran alat praktik sangat penting dilakukan untuk menghitung nilai efisiensi alat praktik sesuai dengan status setiap alat. Penyebaran alat praktik agar penggunaan alat praktik optimal. Semua alat di distribusikan secara merata sesuai dengan jumlah alat yang dibutuhkan pada setiap job, tetapi ada beberapa alat yang memiliki sisa untuk cadangan (Hasan, 2008). Nilai efisiensi setelah dioptimalkan yaitu $87 \%$. Kriteria penggunaan peralatan yang ideal untuk menunjang kegiatan pembelajaran praktik memiliki efisiensi berkisar antara 70\%-90\%. Nilai efisiensi setelah dioptimalkan tersebut menunjukkan bahwa penggunaan fasilitas alat praktik efisien.

\section{KESIMPULAN}

Kesimpulan penelitian ini sebagai berikut jenis peralatan yang digunakan ada 41 jenis alat dengan jumlah alat yang bervariasi. Nilai efisiensi penggunaan alat praktik yang selama ini digunakan pada mata pelajaran Pemeliharaan Mesin Sepeda Motor di kelas XI rata-rata $60 \%$, penggunaan alat kerja praktik tidak efisien. Mengoptimalkan fasilitas alat praktik dengan cara mengubah jumlah siswa tiap kelas menjadi enam kelas dengan jumlah 26 siswa dan satu kelas dengan jumlah 27 siswa. Regu kerja dibuat menjadi 13 regu dengan jumlah 
anggota dua sampai tiga siswa, menyebarkan alat sesuai dengan kebutuhan pada setiap job. Pelaksanaan pembelajaran praktik agar lebih optimal maka siswa melakukan praktik tiga kali, setiap job dalam satu semester 15 minggu pertemuan. Nilai efisiensi penggunaan alat praktik setelah dioptimalkan rata-rata $87 \%$, maka penggunaan alat kerka praktik efisien.

\section{DAFTAR PUSTAKA}

Astra Honda Motor. (2011). Panduan Penerapan Teknik Sepeda Motor Honda Sekolah Menengah Kejuruan (SMK). Jakarta: Astra Honda.

Barnawi \& Arifin, M. (2012). Manajemen Sarana dan Prasarana Sekolah. Jogjakarta: ArRuzz Media.

Hasan, B. (2008). Manajemen Industri. Bandung: Pustaka Ramadhan.

Kuswana, W. S. (2013). Filsafat Teknoligi, Vokasi dan Kejuruan. Bandung: Alfabeta

Syafrudie. (2004). Standar Minimal Laboratorium, Workshop, dan Studio Pendidikan Teknologi Kejuruan jenjang S1. Jakarta: Departemen Pendidikan Nasional 